Article

\title{
Leading Schools towards Sustainability. Fields of Action and Management Strategies for Principals.
}

"Change in education is easy to propose, hard to implement, and extraordinarily difficult to sustain" (Andy Hargreaves und Dean Fink ${ }^{1}$ )

\author{
Ulrich Müller ${ }^{1 *}$, Armin Lude ${ }^{2}$ and Dawson R. Hancock ${ }^{3}$ \\ 1 Affiliation 1; ulrich.mueller@ph-ludwigsburg.de \\ 2 Affiliation 2; $\underline{\text { lude@ph-ludwigsburg.de }}$ \\ 3 Affiliation 3; dhancock@uncc.edu \\ * Correspondence: ulrich.mueller@ph-ludwigsburg.de Tel.: +49-7141-140-416
}

\begin{abstract}
Education is expected to support the development of a more sustainable way of thinking, working, and living. Although there is a broad range of literature on Education for Sustainable development (ESD), the role of principals in the implementation of sustainability and ESD in schools has rarely been taken into consideration. However, based on the results of school effectiveness research, one can assume that school principals exert a significant influence on ESD.
\end{abstract}

Sustainability is a leadership issue. When a school aims at integrating sustainability and ESD, the principal plays a pivotal role. She or he has to support the endeavor wholeheartedly and credibly, organize a participative process of school development, push ahead sustainability and ESD in the daily life of the school, support teaching staff in the application of ESD, involve students and offer them opportunities to launch their own initiatives.

This article seeks to support principals in leading their schools towards sustainability. Four stages of the integration of Sustainability and ESD in a school are defined. For each of these stages, a number of actions and management strategies are suggested and explained in detail.

Keywords: leadership; schools; education for sustainable development; ESD; management strategies; principals;

\section{Introduction}

There is widespread agreement that education plays a crucial role in the development of sustainable societies and economic systems. ESD empowers people to think and act for the future in a positive way. It enables each individual to understand the effects of their own actions on the world and encourages them to make responsible decisions. In 2002, the UN General Assembly adopted a resolution to begin the UN World Decade of Education for Sustainable Development. This program ran from 2005-2015 and has been continued in a Global Action Program. A large number of projects have emerged in this context [2,3].

The UN Decade has helped ESD progress a long way, led to numerous innovative projects, and produced an almost incalculable variety of materials and teaching examples. However, it is not only important to address sustainability issues in individual projects and teaching, but also to structurally initiate sustainability in the organizations themselves [4][5] (p. 3). The step must be taken from "project to structure" [6] and sustainability principles need to be integrated into education and training contexts [3] (p. 18).

${ }^{1}[1]($ p. 1$)$ 
Studies show that it is still not possible to assume that ESD and sustainability are firmly established in schools. In Germany, a large-scale study of students (a survey of 2,564 14-24 year olds) showed that under $9 \%$ of the time spent teaching and attending seminars had clear references to sustainability [7] (p. 4). Furthermore, it became apparent in the study that ESD is still predominantly committed to and focused on individuals. A broad and structural anchoring can by no means be assumed [7] (p. 4). Respective data for the U.S.A. is not available, as EDS is relatively new to the American school system and is not firmly established in K-12 curriculum or pedagogy $[8,9,10]$. Due to the ambiguity in assessment tools and the wide range of application approaches used in U.S. K-12 schools, we know little about the success of different implementation strategies [11].

In the Global Action Program "Education for Sustainable Development" (GAP), the successor to the UN Decade of ESD, UNESCO defines "transforming learning and training environments" as one of five priority fields of action: "ESD is about much more than preaching and teaching on sustainable development. It is also about practicing sustainable development. Sustainable learning environments, such as eco-schools or green campuses, allow educators and learners alike to integrate sustainability principles into their daily practice. Transforming learning and training environments concerns not only managing physical facilities more sustainably, but also changing the ethos and governance structure of the whole institution" [3]. For an agenda up to 2030, in 2015 the United Nations Development Program (UNDP) identified a series of seventeen important worldwide goals - referred to as the Sustainable Development Goals (SDGs, $[12,13]$. Education is a crucial part of the SDGs, not only due to its role as goal no. 4 (quality education), but also because it is vital to the possibility of progress on all goals.

\section{Sustainability and ESD as leadership responsibilities}

Few studies have explored ESD implementation and how it relates to school organization [14]. Those that have investigated successful ESD implementation highlight the importance of the school leader [10]. The principal's importance is substantial in assisting teachers to develop ESD pedagogical strategies and establishing the school as an environmental agent within the community [15]. Mogren and Gericke identify proactive leadership among the key aspects of implementation [16]. Other studies have shown that a principal's personal care and commitment to environmentalism and sustainable development plays a big role in implementing ESD in school policy [17, 18]. Distributive leadership and the active integration of involvement from other school staff and community are other key factors that have been identified as essential to an effective ESD program $[15,19,20]$.

A principal's lack of willingness to undergo a school transformation and a dearth of confidence in their own administrative skill are constraining factors of successful ESD implementation [15]. The growth of ESD is also limited by a shortage of time and space in the curriculum [21].

The current insufficient status of ESD in schools could be due to the fact that the aspect of leadership and the role of school management have been given very little consideration. Here, too, the UNESCO program marks a turning point. In the Road Map for the GAP, UNESCO identifies the heads of educational institutions as central target groups [3] (p. 19). In Germany, the Federal Government's National Action Plan on ESD also mentions the "development, testing, consolidation and dissemination of qualification concepts for leaders" in the various learning environments as an important goal [22] (p. 43).

With their actions, school principals exert a decisive influence on life, work, teaching, and learning in a school. School effectiveness research has produced a large amount of empirical evidence that underscores the significance of school management in relation to the quality and performance of a school (for example [23, 24]). The actions of the school management have an important effect on teaching, school climate, self-image and motivation of teachers, and on the learning performance of the pupils [25].

The importance and role of school management in the implementation of sustainability and ESD in schools has rarely been the subject of empirical studies. The results of school effectiveness research, however, allow the conclusion to be drawn that school principals exert a significant influence here. 
The findings of the few empirical studies on ESD that consider school management (e.g. $[5,26])$ also point in this direction.

The holistic transformation of a school into a learning and teaching environment oriented towards sustainability (see above) requires a comprehensive school development process and critical reflection. This should be designed as a holistic process that focuses on the individual school and integrates the development of personnel and teaching, as is recommended for every other type of school development process [38]. The Whole School Approach [27, 28, 29] also broadens the view to include aspects that are usually less often considered in school development, but are of great importance from the point of view of sustainability. These aspects include school finance management, material cycles and resource management, structural design, and equipment [30] (p. 413).

Furthermore, principals must adopt an appropriate attitude and perform management duties accordingly. Rolf Dubs emphasizes that traditional management is not enough to successfully introduce the innovations and quality improvement the school development processes aims to achieve [31] (p. 143). In addition to the management that is necessary to ensure the functioning of a school, a transformational leader must encourage employees to identify with the school, inspire them to engage in something new, and open up opportunities for developing their own initiative. Following Wunderer [32], Dubs defines transformational leadership as engaging in the following forms of behavior:

- "The leaders give expression to their values and visions.

- They try to introduce differentiated values into the leadership process and always reflect on their visions and develop them further in the face of changing environmental conditions.

- They recognize the motives and needs of their employees and try to influence them by transforming existing motives in order to achieve new goals with other motivations.

- They try to increase the attractiveness of goals and tasks.

- They promote the identification of employees with their social system and the tasks to be addressed.

- They inspire employees to take up new challenges.

- They are interested as far as possible in the individual needs and expectations of their employees as individuals " [31] (p. 143) (translated by the authors).

The forms of behavior he mentions are particularly necessary if the school development project is as demanding as anchoring sustainability and ESD in a school.

Current approaches to corporate sustainability management in business enterprises also emphasize the potential of transformational leadership. Kerstin Pichel and Heinrich Tschochohei point out that consideration of sustainability issues in organizations and companies increases the complexity that has to be mastered. The necessary balancing of economic requirements, ecological compatibility, and social concerns makes it necessary to continually assess, revise, and compromise. Considering the quantity and variety of decisions that have to be taken on a daily basis in organizations, this can only succeed if employees are motivated and allowed to act with a degree of independence [33] (p. 154ff.). Managers and employees often require appropriate support in the form of additional training and personnel development [34].

Heather Burns et al. point out that leadership for sustainability builds on but goes beyond transformational leadership. The kind of leadership required "could also be termed as 'facilitation' or 'caring', as the core goal is to guide people and organizations to collaboratively create visions and take action for a more sustainable and resilient world" [35] (p. 90). They question traditional views of leaders which idealize a leader as a person with vision and direction and an "almost enlightened view of hot to manage a situation" who can "wisely guide followers through linear, organized solutions" [35] (p. 91). In contrast, Burns et al. understand the role of a leader as "not to lead others, but rather lead with them". In today's complicated, interconnected and rapidly changing world 
leaders are not expected to provide solutions, but to create opportunities for people to find new solutions [35] (p. 92).

In most schools it is not necessary to start from scratch, but existing initiatives can be taken up. Usually, there are already committed people who are active - perhaps only to a limited extent - and whose cooperation can be counted on. Furthermore, it can be assumed that many pupils and some of the teaching staff are (at least latently) willing to actively support measures related to sustainability. The aforementioned study as part of the national monitoring program in Germany showed that young people would like to see sustainability issues considered to a much greater extent, namely in $34 \%$ of the teaching time [7] (p. 4). In the "Fridays for Future" initiative (fridaysforfuture.org), pupils and students engage in and call for a greater commitment to sustainability, which offers excellent opportunities to build on these demands in the classroom and in school development!

A survey of 525 teachers at general and vocational schools, which was also conducted as part of the monitoring program, showed that they would also like to see ESD significantly intensified. According to the survey, Teachers want to include sustainability in more than $40 \%$ of teaching time [36] (p. 4).

The process of school development towards sustainability can be started as an initiative of the principal or by taking up initiatives of teachers or even students. In any case it will only succeed if it is purposefully promoted by the principal and if it is broadly supported in the school and its social environment. The aim is to stimulate and tap into the problem-solving behavior and creativity of the community. It is the task of the principal to start and organize this participative process in order to win over pupils, teachers, parents, external partners, and the school authorities.

\section{Theoretical Background}

In the following we suggest steps and management strategies to apply when undertaking the endeavor of a school development process towards sustainability. The theoretical framework for this is grounded in the New St. Gallen Management Modell (NSGM) [37]. This model is based on a systems approach to management and leadership and understands management as a system of complex tasks that can be summarized as designing, controlling, and further developing purposeoriented socio-technical organizations [37] (p. 11). It distinguishes between six central categories that relate to the inner dimensions of management: environmental spheres, stakeholders, interaction issues, structuring forces, processes, and modes of development. Several authors already have adapted the NSGM for educational leadership and management [38, 39, 40]. With its understanding of organizations as complex systems imbedded in environmental spheres, the NSGM perfectly fits to ESD where an ecological view and systems thinking are essential theoretical perspectives. In the following, we refer to the NSGM and the mentioned adaptations for educational institutions as a structuring framework and use selected categories of the model as guiding principles.

\section{Stages on the Way to a Sustainable School}

From a pragmatic perspective, one can distinguish four stages of integration of sustainability and ESD in a school:

- Stage 0: Sustainability is not (yet) an Issue

There are no significant activities in the school with regard to sustainability and ESD.

- $\quad$ Stage I: Projects

Individual teachers take up ESD topics in class; occasionally there is interdisciplinary cooperation and individual activities such as the creation of a school garden.

- $\quad$ Stage II: System

The school as a whole is systematically oriented towards sustainability and ESD. Sustainability and ESD are integrated into teaching and school life in a variety of ways. The teaching staff largely 
supports the cause and is involved in the development of teaching concepts and projects such as the construction of a solar plant, the re-design of the school grounds, or cooperation with external partners. The school is managed in accordance with criteria of sustainability.

\section{- $\quad$ Stage III: Profile}

As with Stage II, the school as a whole is systematically oriented towards sustainability and has integrated ESD comprehensively into teaching and school life. In addition, the school has made sustainability a key issue and developed a specific sustainability school profile.

Starting from each stage, further steps and changes are possible. In the following section, possible measures are described in detail.

\section{Fields of Action and strategies for principals ${ }^{2}$}

The diagram below gives an overview of the steps and fields of action in which principals can become active. The step from Stage 0 to Stage I is a low-threshold entry and should be possible at many schools. The step from Stage I to Stage II is more demanding and requires careful preparation.

Practical steps that occur across different stages are highlighted in grey, those specific to one stage have a white background. The actions listed in Stage II: "System" are intended to be a checklist. In each individual case, the school and program must be examined. At this point, the purpose must be decided and the prevailing local conditions need to be considered. Some things may not seem feasible at first, but creative solutions can often be found at the second or third attempt.

The individual steps here are depicted as a linear process. In many fields, however, the individual steps are closely linked to each other and must be seen as connected. For example, the fields of Participation/Motivation and Information/Communication are closely related to each other and cannot be approached independently. An iterative, experimental approach is therefore recommended, in which steps in the process are continually linked back to the previous ones and a step backwards is also possible, e.g. to rethink and sharpen basic assumptions. Thus, if necessary, goals must be changed and planned measures adapted.

2 The suggested strategies are based on and informed by an evaluation of literature on school development, educational leadership, general management and ESD. For the sake of readability, references are given only if one specific source is especially noteworthy. 

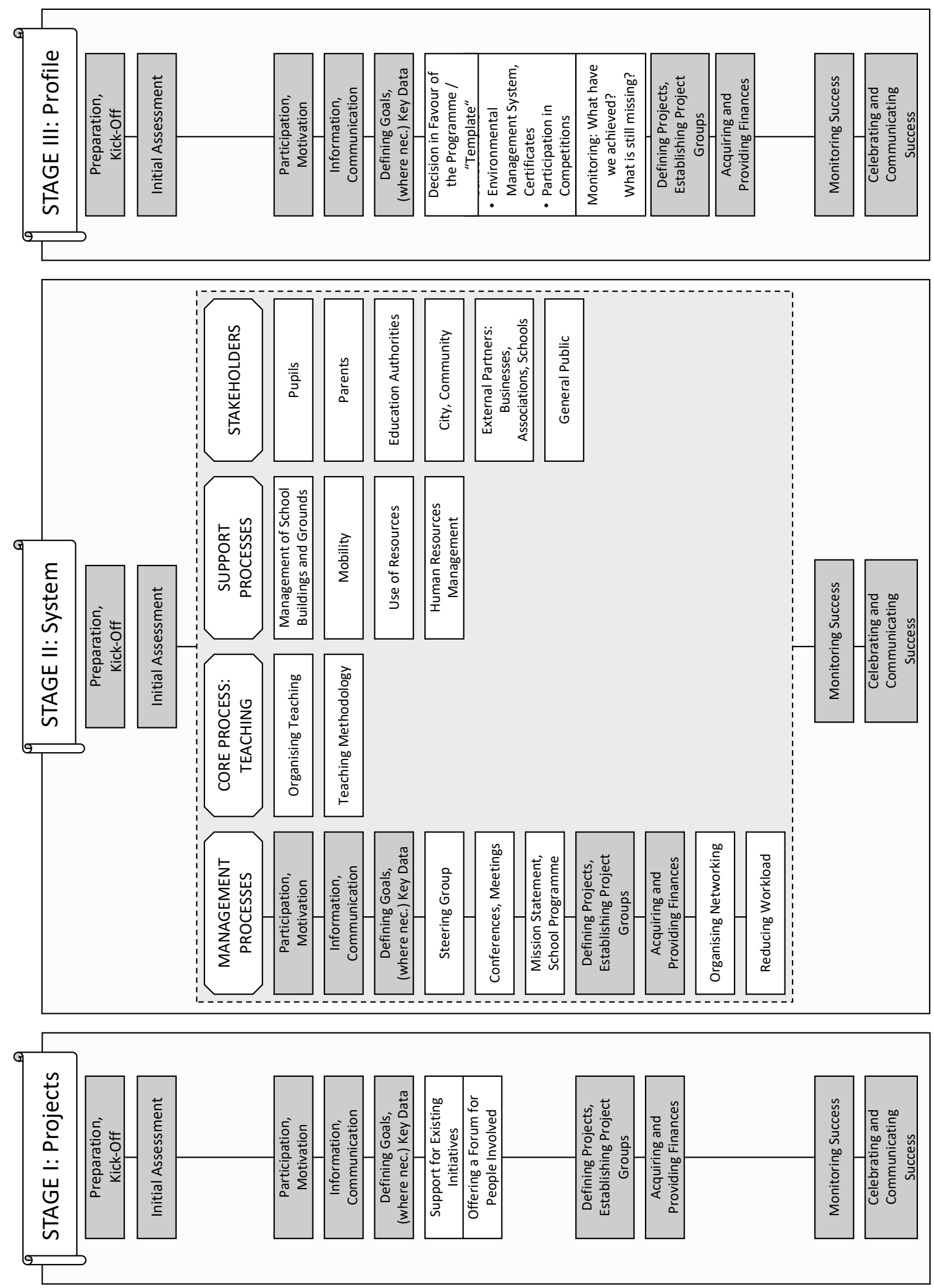

Figure 1: Sustainability and ESD: fields of action for school management. Practical steps that occur across different stages are highlighted in grey, those specific to one stage have a white background (devised by the authors).

In the following, the practical steps are described in more detail. The description starts with Stage II, as this is the most differentiated. The specific steps for Stages I and III are described after. 


\section{Preparation and Kick-off}

The decision to implement a school development process for sustainability and ESD should be taken with the broadest possible participation. It is advisable to present the proposal to the decisive committee at an early stage and to discuss it together. However, this should be carefully prepared and presented convincingly. If the impetus comes from the school management, it must first deal with it itself and inform itself. Where possible, attempts should be made to hold discussions with principals or representatives of schools which have already successfully completed the process.

The support of the school authorities will be needed at many points throughout this process and must therefore be involved from the outset.

Finally, an official start is needed to set the process in motion. The kick-off should take place as a plenary event with the participation of all relevant interest groups and should also be communicated publicly.

Initial Assessment

The next step is to take stock of where the school stands. Future steps and practical measures can be decided once the position of the school is known.

It is not necessary to plan everything from the beginning. Because the procedure is designed to be participatory, it is important to leave time and space for pivots and alterations to the plan as those involved add to the culture and direction.

At Stage III: Profile, it is advisable to carry out the assessment after or simultaneously with the decision to implement a program. This ensures that evaluation can be carried out with regard to the required criteria.

\section{MANAGEMENT PROCESSES}

\section{Participation and Motivation}

Participation is a central principle of ESD. Consequently, the process of sustainable school development must also be participatory. This includes:

- democratic decision-making as far as possible within the legal framework. In order to maintain the motivation of the participants in the long term, it is essential to present the framework within which groups can actually make decisions transparently and honestly.

- a collaborative distribution of tasks

- the broadest possible involvement of all relevant groups of participants

- cooperation of all actors.

For the school management, this means being able to show restraint, to hand over responsibilities, to create scope for initiative and participation - and to value commitment.

The integration of sustainability and ESD is a long-term and sometimes laborious process that demands staying-power from all those involved. A central task of the school management is to support motivation and commitment. Central elements of motivating leadership characteristics are attentiveness, appreciation, and positive feedback. This is a fundamental attitude which may also require managers to "work on themselves".

Research has shown that although the communication of crisis scenarios can increase sensitivity to environmental problems, it can also cause fears and defence mechanisms that only bring about behavioral changes to a limited degree [41]. The motivation for lasting reform efforts is supported by focusing on one's own activity ("We are doing something"), on positive results, and on opportunities for actually making a change.

\section{Information and Communication}

Information and communication are the central prerequisites for participation; without them, there is no participation. It is therefore essential to proactively inform all relevant groups and 
organizations (see below: Stakeholders) involved in the process about the project. This involves the dissemination of information by the school management and the steering group resp. ESD group (see below). It is essential that channels of communication are as broad and varied as possible for the flow of information and feedback to be effective.

Comprehensive communication at the start is a matter of course, but it must also take place in all other steps. This can be done through regular status reports, progress reports, and planned activities in the form of conferences, circulars etc. The overall project requires a well thought-out communication strategy and professional communication procedures [42].

Defining Goals and, if necessary, specifying them more precisely using Key Data

Every development or change process requires defined goals that set the direction. When defining goals, the overall project must be kept in mind and a balance must be struck between various interests. Exaggerations in one area often lead to undesirable side effects in others.

Where possible, targets should be further specified by key data. This is obviously possible for all projects aimed at saving energy or resources (30\% reduction of energy consumption by year..., etc.).

However, the entire project should also be designed with a certain openness. The objectives set the direction to be taken, but can often only take on a more concrete form over the course of the process. For example, new partners may be included with new ideas requiring a course correction. It is also possible to implement the practical measures from the different stages in a different order than prescribed in the chart and instead use them as a kind of construction kit. For example, measures to re-design the school grounds (Stage II) can also be carried out as a project in Stage I.

Setting up a Steering Group and ESD Team

Steering groups play an important role in the school development processes and are often the central body for their coordination and management [43]. If a school already has a steering group, it should be included in the process. If not, one should be established.

Consideration should be given here as to whether the already existing steering group should also take on full responsibility for sustainability or whether there should be a separate "ESD team" [5] (p. 193ff.). Project teams (see below) can also be set up for individual projects or specific sectors (curriculum development, finance management, etc.). The structure should be appropriate to the size of the school and not overly-complex. Open and regular communication between the respective teams is crucial for success. Whether as a school steering group or as an ESD team, the committee should always be composed of members from different groups and, if possible, external members.

\section{Conferences, Meetings}

Opportunities to discuss content and exchange ideas are always need for the entire school, management team, steering group, and project teams. Conferences and meetings provide such opportunities.

\section{Mission Statement and School Program}

In a so-called mission statement, the school members formulate the jointly developed and supported principles and orientation of a school [44] (p. 330). If a school decides to focus more on ESD and sustainability, this must be expressed in the mission statement. The school should therefore revise the mission statement to include sustainability in its orientation over the course of the development process.

The situation is similar with the school program. This is a comprehensive work program in the sense of a pedagogically oriented and future-directed development plan, including goals, practical measures and, if possible, ideas for evaluation and further training [44] (p. 321). The school program is the central document in which the project must be fully represented. In order for them to become binding principles, sustainability and ESD must be anchored in the mission statement and school program. 
The Grundmann study mentions models and school programs as among the most important instruments of school development for ESD [5] (p. 160). Therefore, it is crucial that they are actually developed in a participatory process in which all members of the school are involved [5] (p. 162). The mission statement and the school program can only become effective if the daily work of the school is based on them and is monitored frequently with regard to the agreed principles [5] (p. 163).

\section{Defining Projects and Setting up Project Groups}

Some changes to be addressed within the framework of the school development process for sustainability are relatively straightforward and simple tasks that only require a decision to be implemented. Many tasks, however, are extensive and require long-term "staying power" (such as the development or revision of the school). These tasks can be handled by project teams that can devote themselves to the task over a longer period of time [45]. As mentioned above for the steering group, the broadest possible participation of various stakeholders should always be the goal.

\section{Providing and Acquiring Finances}

Funding must be made available for the entire process and for many individual measures. Even if many measures help to save costs in the long term, investments are often necessary. An important element of project planning is the budgeting of the practical measures. It is also absolutely essential to involve the school authorities at an early stage and convince them of the need to support the project. For some measures, funds can also be raised from external sponsors, e.g. foundations or companies. There are also models in which half the savings in running costs (in particular energy costs) achieved by the measures taken are made available to the school (fifty-fifty projects; www.fiftyfifty.eu). In this way, the school and school authorities benefit from the intervention.

\section{Organizing Networking}

Networking with external actors, such as other schools and external non-educational partners, is an important factor for success in school development for sustainability. By opening up the school to outsiders and cooperating with them, important insights can be gained and support organized in many of the fields of action listed here.

Prospective partners in the process can be:

- federal state institutions, ESD networks and multipliers, e.g. through participation in further training, consultation and support for the school development process,

- environmental education centers, museums, companies, (local) companies with a focus on sustainability, associations that can be used as extra-mural learning environments,

- universities, students, other external professionals, other schools that can take over some of the teaching or can participate in internal further training courses,

- (international) partner schools, global school networks, which can offer exchange, information, inspiration, or advice.

\section{Reducing the Workload}

Schools, school principals, and teachers are under increasing pressure and an increasing workload. The pursuit and implementation of sustainability goals can fail because they are often not perceived as immediately urgent tasks by school staff. The pressures and numerous urgent tasks that occur in the everyday environment of a school are in direct competition with ESD. Therefore, ESD and sustainability implementation is often given a lower priority and is continuously postponed. In order to create favorable conditions for sustainability in schools, an important starting point is to first reduce the workload elsewhere. This should be communicated at an early stage and tackled resolutely. Possible guiding questions for this are:

- How can we create the space and time to provide resources for the new goal of sustainability? 
- Which internal procedures, processes and conditions create stress? How can we simplify them and make them more efficient? Which ones can we do without completely?

- What external conditions do we perceive as stress factors? What can we do to reduce these factors or to deal with them more effectively?

Fredmund Malik has described the solution of "systematic waste removal" for the implementation of this task. He understands this as a scheduled review of procedures, processes, documents, and habits which are really needed [46] (p. 365ff.).

However, the education authorities - the local authorities and the Ministry of Education - also have a special responsibility here. When schools are overrun with ever new requirements, there is little room and time for long-term projects such as school development for sustainability.

\section{CORE PROCESS: TEACHING}

Students learning is at the focal center of a school. The whole process of school development for more sustainability is therefore essentially aimed at redesigning the teaching and learning processes. These aspects are already comprehensively considered in publications on ESD, which is why we will limit ourselves here to just a few thoughts.

Since ESD is a comprehensive approach, integration is possible in all subjects and not only in the "classical" ESD-related subjects of biology and geography. ESD learning processes are characterized by interdisciplinary and transdisciplinary approaches, systemic approaches, differentiated learning, and pupil participation. ESD therefore does not always require additional teaching time, but is a different and new way of looking at already well-known subject areas.

For Germany, e.g. a competence-oriented proposal has been drawn up for all subjects in the Orientation Framework for the Learning Area of Global Development [47]. Various online portals offer a searchable database of teaching materials ${ }^{3}$.

Teaching Methodology

- Which subject areas are particularly suitable for promoting ESD competences?

- Which teaching principles (action-oriented, interdisciplinary, ... teaching), which learning locations (extracurricular learning locations such as museums, natural areas, ...), and which methods (project work, explorations and research, discussions, workshops, ...) should be employed in teaching?

Organizing Teaching

- What framework conditions are needed to be able to implement learning arrangements such as those mentioned above?

- How can these framework conditions be created?

- How can teachers be supported in applying ESD principles and using appropriate forms of teaching?

\section{SUPPORT PROCESSES}

Human Resources Management

If a school makes sustainability a central component of its strategy and orientation, then it is essential to implement an orientation and a corresponding strategy for personnel employment and development. The implementation of sustainability and ESD in everyday school life largely depends

${ }^{3}$ eg: Education for Sustainable Development Toolkit, www.esdtoolkit.org; learning for a sustainable future, www.lsf-lst.ca; Sustainable Development Goals - Resources for educators, en.unesco.org/themes/education/sdgs/material; Smithsonian Science for Global Goals, ssec.si.edu/global-goals. 
on the staff (above all the school management and the teachers) supporting the mission and possessing the necessary competences.

Distribution of Tasks and Personnel Deployment

- Setting up a functional office for a coordinator for ESD or sustainability officer. The jobholder should be a member of the Extended Executive Board of the school - if possible. Teachers taking over this responsibility should be released from a part of their teaching duties; if this is not possible: are there other forms or measures of compensation? This function should be included in the job and task description

- Including tasks related to sustainability in the job descriptions of other occupational groups (e.g. technical services: implementation of energy-saving measures).

\section{Selection of Personnel}

- If teaching positions are advertised on the open market, include ESD competences in the job advertisement

- Where teachers are assigned to a school by the school inspectorate, include school supervisors in the overall project and ask them to consider the issue when assigning staff.

Personnel Evaluation and Remuneration

- Are there ways to take commitment to sustainability and ESD into consideration in the system of employee evaluation and remuneration?

Personnel Development

- Making teachers and other staff aware of external training opportunities, encouraging participation, or supporting relevant initiatives (training for ESD multipliers etc.).

- Organization of internal school training with external instructors or internal ESD multipliers.

- If necessary, also considering and supporting longer-term measures (multi-part courses, compact studies, etc.).

- Financing more expensive measures through sponsoring.

- Participation of the school principal in suitable further training measures. This can also additionally promote the willingness of teachers to undergo further training.

Team Development

- Personnel development is not only aimed at individuals, but also includes measures involving the entire team:

- Organization of study meetings/educational workshops on the subject of ESD

- Organization of teacher/student seminars: a group of teachers and trainees jointly develops and tests ESD modules

- Organization of peer observation, team-teaching, or joint planning of teaching units and sequences

- Establishment and use of appropriate forms and practical measures of knowledge management, e.g. a joint virtual hard drive for sharing documents, teaching plans and materials; mapping of existing materials

- In addition to these direct measures, it is the responsibility of the school management to promote and maintain a climate of cohesion and mutual support in the school. This relates to communication and interaction in general. Here, the principal acts as an important model through their own communication behavior and shapes the organizational culture of the school. It is also a matter of developing organizational structures that facilitate communication and exchange, e.g. organizing times and places where teamwork is possible. Initiative and commitment flourish where there is freedom, trust, and support. 


\section{Leadership}

- In all the measures mentioned above, the principal plays a decisive role - be it as initiator or supporter - but also simply by paying attention to the relevant tasks and responsibilities and to the people who have taken over responsibility for them. The principal plays a particularly important role in personnel management. In direct communication with teachers and all other employees, school leaders can repeatedly include the topic of sustainability on the agenda for school conferences, set an example with their own actions and decisions, and motivate others by their own commitment - even become an inspiration.

Management of the School Building and Grounds

A school affects its environment in a variety of ways. If energy-saving measures are discussed in class, but the school itself is wasteful with energy or other resources, this undermines credibility.

In line with the Whole School Approach, aspects of sustainability must therefore also be taken into account in the design and management of the school building. A school that is exemplary in this sense acts not only as a role model for the pupils and their parents, but can also spread its influence to the community.

Many of the following measures can and should also be linked to teaching projects. When making decisions, it makes sense to involve the pupils in a participatory way. Furthermore, in many of the interventions mentioned here, the school authorities and, if necessary, the architects must be involved in a suitable manner.

\section{Building Management}

- Can the building be made more sustainable through energy-saving measures (e.g. thermal insulation etc.), sustainable energy technologies (e.g. installing solar panels) or other resourcesaving measures (e.g. a rainwater collection system)?

- Are there opportunities for façade- or roof-greening?

Procurement and Resource Management

- Measures for the economical use of water (toilet flushing, ...)

- Waste separation and use of recycling systems

- Purchase of ecologically and socially sustainable consumables (e.g. recycled products) and longlasting products

\section{School Grounds}

- How can the school grounds be redesigned (e.g. the creation of a school garden, the creation of biotopes such as ponds or orchards, "green", near natural playgrounds)?

\section{Catering}

- Offering sustainable catering for pupils and teachers.

- Purchasing sustainable food (e.g. Fairtrade, products from organic farming, regional and seasonal products)

Mobility

- Is the school easily accessible by public transport? Can the situation be improved if necessary?

- Can the school support the formation of carpools, e.g. at parents' evenings and public events and/or by supporting carpool apps?

\section{STAKEHOLDERS}

Various groups within and outside the school have interests in the school. For the project to succeed, it is essential to involve these groups in the participatory process, or at least to inform them 
of all the steps involved. An information strategy is recommended in which times and information channels (e.g. information letters, e-mail newsletters, homepage, social media) for the individual groups are defined.

Pupils

The pupils are the focus of the school. ESD aims at "Gestaltungskompetenz" or shaping competence [48]. It is therefore essential to comprehensively involve them in the process of the sustainable design of their school and to allow them to share and participate in formulating decisions. This concerns teaching, where, for example, the choice of project topics can be decided jointly. In sustainable pupils' companies, young people learn successful management in an ecologically and socially responsible manner and acquire a wide range of skills that are important for solving problems relevant for the future. Pupils should also be represented and able to participate in committees such as the steering group and the ESD team. The key question for this joint effort is: "How do we want to make our school sustainable and future-oriented?" Pupils can often contribute innovative and exceptional ideas. They also learn in the process what it takes to implement formative ideas in a democratic society. It is important to start with small, promising applications to avoid the loss of momentum that sometimes sets in in larger projects.

\section{Parents}

It is also essential for pupils' parents to be involved in the participatory process. Possible measures [49] (p. 10) include:

- Informing them about contents/projects and their objectives (e.g. at a parents' evening, in letters to parents, presentations),

- Justifying and explaining to them the use of certain teaching/learning methods,

- Opening up opportunities for them to contribute their own suggestions or contributions to the planning of projects or the search for experts (e.g. in the design/redesign of the school grounds),

- Inviting parents to events at the school,

- Discussing individual, far-reaching measures with parents and making joint decisions (e.g. on the introduction of fair and ecologically produced school clothing),

- Involving parents in advising pupils' companies,

- Organizing joint sustainable celebrations,

- Making school trips CO2-neutral (choice of destinations and means of transport, offsetting their carbon footprint)

\section{School Authorities and Supervisors}

The early involvement and close cooperation with the school authorities and school inspectorates is essential. Many decisions, e.g. regarding school construction, financial management, or the school grounds can only be made together with the school authorities.

\section{The City, Municipality}

In smaller towns and municipalities, the mayor may be won over as a patron of the process and may give the event additional importance and attention on special occasions, e.g. at the kick-off event. Local authorities, e.g. nature conservation authorities, the authorities responsible for water and energy supply or waste and sewage disposal can advise and support.

The general public

- Information on the overall process, e.g. through press reports and public events

- Addressing local sustainability issues

- Inviting the general public to events

Monitoring success 
As with any planned process, school development for ESD also requires a procedure for monitoring success. Ongoing tasks must be checked to see whether the objectives have been achieved and if further action is required. Monitoring must also take place as a final step in which the overall project is evaluated.

\section{Celebrating progress and success}

Celebrating progress and success is important for maintaining the overall atmosphere and motivation levels within the school ("we are proud to share ..."). Therefore, celebrations should be held not only at the end of projects, but also for intermediate results. At such points, especially after the exertion of great effort, it can also be useful to take a "breather" before embarking on the next venture. Celebrations can also be combined with public events at which (preliminary) results are presented.

The steps presented so far concern Stage II. Some of the steps are repeated in Stages II and III. In the following, the steps from Stages II and III that have not yet been mentioned are explained. These are referred to as stage-specific steps and are shown in white in Figure 1.

\section{Only in Stage I: Projects}

Supporting Existing Initiatives / Providing an Arena for People Already Involved

At Stage I, "Projects", it will often turn out in the course of the initial assessment that there are already individual sustainability initiatives by teachers or pupils that have yet to be noticed by the school. It is the task of the principal to support these initiatives and to offer the participants an arena where they can present their activities. This is an opportunity for other members of the school to join in. In this way, further projects, awareness, and support can grow out of these "germ cells" of sustainability.

It cannot be emphasized enough how important it is that the principal appreciates the commitment of the participants and publicly expresses this appreciation.

Only in Stage III: Profile

Choice of a Program / a "Template"

At Stage III, "Profile", it must be determined which type of profile is to be pursued. Should participants take part in a specific program in order to obtain an (inter)national quality label (e.g. "Environmental School in Europe/International Agenda 21 School", "UNESCO Project School") or certification through an environmental or sustainability audit (e.g. EMAS certification) [5] (pp. 158ff. and 174ff.)? The individual programs set different priorities and requirements. It is important to consider whether to adopt a program for which the school has pre-existing contributions or to pursue a program that sets the school in a new direction. Even without participating in such programs, the school can give itself a sustainability profile. Here it can be helpful to orientate oneself towards another school and to use this as a guiding "template" ("That's what we also want to do...", "But not that ..." etc.).

Taking Stock: What do we already have? What is missing?

Once a decision has been made to participate in a program, a new goal-directed assessment can be carried out based on the requirements formulated there.

\section{Dealing with Difficulties and Resistance}

The orientation of a school towards the guiding value of sustainability represents a complex and far-reaching process of change that can generate resistance. Systems try to maintain the status quo. Resistance to change is a complex topic and cannot be dealt with exhaustively within this chapter. In 
any event, it is necessary to take a close look and examine the reasons and motives. A few thoughts are offered in the following.

John Kotter and Leonard Schlesinger [50] propose five strategies for dealing with resistance to change. A brief look at this portfolio is worthwhile because it confirms the importance of some of the strategies outlined above.

- Communication: Resistance can be a reaction to a lack of information. It is therefore crucial for success to provide comprehensive information and communication - and to ensure that the information reaches the addressees. An "e-mail to all" is often not the best way to communicate.

- Participation: Opportunities for participation offer employees affected by change the opportunity to have their own interests included and to participate in shaping them. Those who have been able to participate in the decision-making process generally work better on the implementation of the decisions and are more willing to contribute their knowledge.

- Promotion and support: If employees are worried that they will not be able to cope with changing circumstances, new requirements, or processes, measures targeted to impart the necessary knowledge and skills can help. It is often also a question of emotional support and the confirmation that they will be able to cope with the planned changes.

- Negotiation and agreement: If individuals or groups experience disadvantages due to the changes, agreement can often be reached with the help of specifically designed compensation.

- Compulsion: This fifth strategy by Kotter \& Schlesinger [50] - with clear warnings of possible negative side effects - is out of the question at school and in the process of school development aimed at ESD. On the one hand, school principals often do not have the necessary means and competences to be able to exercise effective coercion; while, on the other hand, the exercise of coercion diametrically contradicts the participatory approach of ESD.

The measures for dealing with resistance described here are sometimes costly and timeconsuming. However, this effort almost always pays off because the results are ultimately better than when simply trying to overpower resistance. In addition, many objections and skeptical considerations contain a kernel of truth, which includes important information for the process and should not be ignored.

\section{Perspectives}

Sustainability and ESD are not "add-ons", as they may initially appear to be. They are rather central elements of education; the perspective of a future worth living for the next generation is a fundamental condition and prerequisite for education and upbringing. The Swedish schoolgirl Greta Thunberg, who organizes student strikes and now finds followers all over the world, has put it in a nutshell: "And why should I be studying for a future that soon may be no more, when no one is doing anything to save that future? And what is the point of learning facts when the most important facts clearly mean nothing to our society?"4. However, one judges the school strikes, schools must take the students' concerns and interests that they are fighting for seriously and deal with them. Schools themselves have the responsibility to become active for sustainability and climate protection.

Especially in times when multilateral action and supranational understanding are increasingly being called into question again and nationalistic tendencies are gaining ground in many countries, it is necessary to counter these tendencies with education. The next generations need strategic plans and examples of good practice which rely on an understanding that transcends nations, ethnic groups, religions, and borders. Sustainability is a suitable social guiding value in education for this purpose. Sustainable schools can act as living examples and living laboratories.

Author Contributions: Conceptualization, Ulrich Müller; Data curation, Ulrich Müller, Armin Lude and Dawson R. Hancock; Investigation, Ulrich Müller, Armin Lude and Dawson R. Hancock;

\footnotetext{
${ }^{4}$ See: https://www.youtube.com/watch?v=Hq489387cg4.
} 
Methodology, Ulrich Müller; Project administration, Ulrich Müller; Resources, Ulrich Müller, Armin Lude and Dawson R. Hancock; Visualization, Ulrich Müller; Writing - original draft, Ulrich Müller; Writing - review \& editing, Armin Lude and Dawson R. Hancock.

Funding: This research received no external funding.

Conflicts of Interest: The authors declare no conflict of interest. 


\section{References}

1. Hargreaves, A.; Fink, D. Sustainable Leadership. Jossey-Bass: San Francisco, USA, 2006.

2. UNESCO. UN Decade of Education for Sustainable Development 2005-2014. The DESD at a glance. UNESCO: Paris, France, $2005 . \quad$ Available online: http://unesdoc.unesco.org/images/0014/001416/141629e.pdf (accessed on 7 June 2019).

3. UNESCO. Roadmap for implementing the Global Action Programme on Education for Sustainable Development. UNESCO: Paris, France, 2014. Available online: https://sustainabledevelopment.un.org/index.php?page=view\&type=400\&nr=1674\&menu=35 $($ accessed on 1 July 2019).

4. Laurie, R.; Nonoyama-Tarumi, Y.; McKeown, R.; Hopkins, C. Contributions of education for sustainable development (esd) to quality education: A synthesis of research. J Educ Sustain Dev 2016, 10(2). pp. 226242.

5. Grundmann, D. Bildung für nachhaltige Entwicklung in Schulen verankern. Handlungsfelder, Strategien und Rahmenbedingungen der Schulentwicklung. Springer VS: Wiesbaden, Germany, 2017.

6. Deutsches Nationalkomitee für die UN-Dekade BNE. Positionspapier „Zukunftsstrategie BNE 2015+“. Deutsche UNESCO-Kommission e.V. (DUK): Bonn, Germany, 2013.

7. Grund, J.; Brock, A. Bildung für nachhaltige Entwicklung in Lehr-Lernsettings. Quantitative Studie des nationalen Monitorings. Befragung junger Menschen. Executive Summary. Institut Futur: Berlin, Germany, 2018.

8. Feinstein, N.W.; Carlton, G. Education for Sustainability in the K-12 Educational System of the United States. In Schooling for sustainable development in Canada and the United States (Vol. 4), McKeown, R., Nolet, V., Eds.; Springer Science \& Business Media: Dordrecht, Netherlands, 2013.

9. Smith, K. The Status of Education for Sustainable Development (ESD) in the United States: A 2015 Report to the U.S. Department of State. Available online: https://drive.google.com/file/d/0B7Mfdstcr8GWclZLXzJCUFpQaUJvRERpTmtva011Q1VmLWZZ/view (accessed on 1 July 2019)

10. Warner, B.; Elser, M. How do sustainable schools integrate sustainability education? An assessment of certified sustainable k-12 schools in the united states. J Environ Educ 2015, 46(1), pp. 1-22.

11. Veronese, D.; Kensler, L. School leaders, sustainability and green school practices: An elicitation study using the theory of planned behavior. J Sustain Educ 2013, 4.

12. UN - United Nations. Sustainable Development Goals. 17 Goals to transform our world. 2015. Available online: https://www.un.org/sustainabledevelopment/development-agenda/ (accessed on 7 June 2019).

13. UN - United Nations. Transforming our world: the 2030 Agenda for Sustainable Development. A/RES/70/1. 2015. Available online: https://sustainabledevelopment.un.org/content/documents/21252030\%20Agenda\%20for\%20Sustainable\% 20Development\%20web.pdf (accessed on 7 June 2019).

14. Mogren, A.; Gericke, N; Sherp, H. Whole school approaches to education for sustainable development: A model that links to school improvement. Environ Educ Res 2018, 25(4), pp. 508-531. DOI: 10.1080/13504622.2018.1455074

15. Kadji-Beltran, C.; Zachariou, A.; Stevenson, R. Leading sustainable schools: Exploring the role of primary school principals. Environ Educ Res 2012, 19(3), pp. 303-321.

16. Mogren, A.; Gericke, N. ESD implementation at the school organization level, part 1- investigating the quality criteria guiding school leaders' work at recognized ESD schools. Environ Educ Res 2017, 23(7), pp. 972-992.

17. Desfandi, M.; Maryani, E.; Disman, D. The role of school principal leadership in implementation of eco school programs as the effort to support sustainable development. In Advances in Economics, Business and Management Research, volume 14, Proceedings of the 6th International Conference on Educational, Management, Administration and Leadership (ICEMAL2016), Bandung, Indonesia, 28 August 2016. pp. 197-200.

18. Schelly, C.; Cross, J.; Franzen, W.; Hall, P.; Reeve, S. How to go green: Creating a conservation culture in a public high school through education, modeling, and communication. J Environ Educ 2012, 43(3), pp. 143 161.

19. Leo, U.; Wickenberg, P. Professional norms in school leadership: Change efforts in implementation of education for sustainable development. J Educ Change 2013, 14(4), pp. 403-422. 
20. Mogren, A.; Gericke, N. School Leaders' Experiences of Implementing Education for Sustainable Development-Anchoring the Transformative Perspective. Sustainability 2019, 11, 3343. DOI: 10.3390/su11123343.

21. McKeown, R., Nolet; V., Eds. Schooling for sustainable development in Canada and the United States (Vol. 4. Springer Science \& Business Media: Dordrecht, Netherlands, 2013.

22. BMBF - Bundes-Ministerium für Bildung und Forschung, Nationaler Aktionsplan für nachhaltige Entwicklung. Der deutsche Beitrag zum UNESCO-Weltaktionsprogramm. Nationale Plattform Bildung für nachhaltige Entwicklung: Berlin, Germany, 2017.

23. Feige, C. Effektives Management von Bildungseinrichtungen. Eine empirische Vergleichsstudie zur Identifikation erfolgsrelevanter Handlungsdimensionen des Managements für die pädagogische Wirksamkeit von Schulen und Erwachsenenbildungseinrichtungen. Der Andere Verlag: Uelvesbüll, Germany, 2012.

24. Leithwood, K.; Jantzi, D. Linking leadership to student learning: the contributions of leader efficacy. Educ Adm Q 2008, 44(4), pp. 496-528.

25. Hatti, J. Visible Learning. Routledge: London, England and New York, USA, 2009.

26. Rode, H. Motivation, Transfer und Gestaltungskompetenz. Ergebnisse der Abschlussevaluation des BLKProgramms “21” 1999-2004. Institut Futur: Berlin, Germany, 2005.

27. Ferreira, J.-A. L.; Ryan, L.; Tilbury, D. Whole School Approaches to Sustainability: A review of models for professional development in pre-service teacher education. 2006.

28. Mathar, R. Whole school approach to ESD - contribution to implement the SDGs in general. Proceedings of the International Conference Education as a Driver for Sustainable Development Goals, Ahmedabad, India, 11-13 January 2016

29. Robinson, W.; Campbell, J. Effective teaching in gifted education. Using a whole school approach. Routledge, Abingdon, England, 2010.

30. Mathar, R. Der Lernbereich Globale Entwicklung als Aufgabe der ganzen Schule. In [21]. pp. 412-432.

31. Dubs, R. Führung. In Professionswissen Schulleitung, Buchen, H., Rolff, H.-G., Eds.; Beltz: Weinheim, Germany and Basel, Swiss, 2006. pp. 102-176.

32. Wunderer, R. Führung und Zusammenarbeit: Eine unternehmerische Führungslehre. Luchterhand: Neuwied, Germany, 2003.

33. Pichel, K.; Tschochohei, H. Leadership für nachhaltiges Wirtschaften. In Betriebliches Nachhaltigkeitsmanagement, Baumast, A., Pape, J., Eds.; Eugen Ulmer: Stuttgart, Germany, 2012; pp. 153-174.

34. Müller, U. Nachhaltigkeit - (k)ein Thema für die betriebliche Personal- und Führungskräfteentwicklung? In Wert und Werte im Bildungsmanagement, Schweizer, G., Müller, U., Adam, T., Eds.; Bertelsmann: Bielefeld, Germany, 2010; pp. 327-336.

35. Burns, H.; Diamond-Vaught, H.; Bauman, C. Leadership for Sustainability: Theoretical Foundations and Pedagogical Practices that Foster Change. Int J Leadersh Stud 2015, 9(1), pp. 88-100.

36. Brock, A.; Grund, J. Bildung für nachhaltige Entwicklung in Lehr-Lernsettings. Quantitative Studie des nationalen Monitorings. Befragung von LehrerInnen. Executive Summary. Institut Futur: Berlin, Germany, 2018.

37. Rüeg-Stürm, J. The New St. Gallen Management Model. Basic Categories of an Approach to Integrated Management. Palgrave MacMillan: Houndmills, England, 2004. DOI: 10.1057/9780230505162

38. Dubs, R. Die Führung einer Schule: Leadership und Management. Franz Steiner, Zürich, Swiss, 2005.

39. Müller, U. Bildungsmanagement - Skizze zu einem orientierenden Rahmenmodell. In Lernen am Unterschied: Bildungsprozesse gestalten - Innovationen vorantreiben, Schweizer,G., Iberer, U., Keller, H., Eds.; Bertelsmann: Bielefeld, Germany, 2007; pp. 99-121.

40. Seufert, S. Bildungsmanagement. Einführung für Studium und Praxis. SchäfferPoeschel: Stuttgart, Germany, 2013.

41. Steg, L.; van den Berg, A.E.; de Groot, J.I.M. Environmental psychology: an introduction. Wiley-Blackwell: Chichester, England, 2013.

42. Soland, M.; Müller, U.; Kohrs, J.-T. Herausforderung Kommunikation: Grundlagen und Leitfäden für Steuergruppen. In Handbuch für Steuergruppen, Carl Link: Köln, Germany, 2019; pp. 372-378.

43. Huber, S.G. Handbuch für Steuergruppen. Grundlagen für die Schulentwicklung und das Schulmanagement. Karl Link: Köln, Germany, 2019.

44. Rolff, H.-G. Schulentwicklung, Schulprogramm und Steuergruppe. In Professionswissen Schulleitung, Buchen, H., Rolff, H.-G., Eds.; Beltz: Weinheim, Germany and Basel, Swiss, 2006. pp. 296-364. 
45. Schett, J. Projektmanagement. In Huber, Stephan G. (Hg.): Führungskräfteentwicklung. Grundlagen und Handreichungen zur Qualifizierung und Personalentwicklung im Schulsystem, Huber, S.G., Ed; Carl Link: Köln, Germany, 2013; pp. 372-378.

46. Malik, F. Führen, Leisten, Leben. Wirksames Management für eine neue Zeit. Campus: Frankfurt, Germany, 2014.

47. KMK - Ständige Konferenz der Kultusminister der Länder in der Bundesrepublik Deutschland; BMZ Bundesministerium für wirtschaftliche Zusammenarbeit und Entwicklung; Engagement Global, Eds.; Orientierungsrahmen für den Lernbereich Globale Entwicklung. (Ed.): Orientierungsrahmen für den Lernbereich Globale Entwicklung: Berlin/Bonn, Germany. Online: www.kmk.org/fileadmin/veroeffentlichungen beschluesse/2015/2015 06 00-OrientierungsrahmenGlobale-Entwicklung.pdf (accessed on 25 January 19). Berlin/Bonn, Germany, 2016.

48. de Haan, G. The BLK '21' programme in Germany: A 'Gestaltungskompetenz' -based model for Education for Sustainable Development. Environ Educ Res 2006, 12, pp. 19-32.

49. Handschuh, K.; Jovanovic, T.; Rajh, T.; Schuldt, C.-M. Nachhaltige Entwicklung und Institution Schule. BNE Qualifizierungsmodule, Modul 7. Ministerium für Kultus, Jugend und Sport and Ministerium für Umwelt, Klima und Energiewirtschaft Baden-Württemberg: Stuttgart, Germany, 2013.

50. Kotter, J. P.; Schlesinger, L. A. Choosing strategies for change. Harv Bus Rev 2008, 7/8. Available online: https://hbr.org/2008/07/choosing-strategies-for-change (accessed on 13 March 2019) 